\title{
The School Manager and the Use of Knowledge Management Practices for Structuring Organizational Processes
}

\author{
Tânia Regina Corredato Periotto \\ Professor of the Post-Graduation Program in \\ Management of the Knowledge in the Organizations \\ UNICESUMAR/ICETI \\ University Center of Maringá - Brazil \\ Janacilda Leite Wessellenns \\ Student of the Post-Graduation Program in \\ Management of the Knowledge in the Organizations \\ UNICESUMAR \\ University Center of Maringá - Brazil
}

\begin{abstract}
Knowledge management gains space within the school organization and can contribute satisfactorily to the quality of teaching. The school manager in everyday routine intuitively uses knowledge management practices without exploiting the potentials they offer or allow. In this context, the purpose of this study is to identify the level of implementation of knowledge management practices aimed at structuring the organizational processes used by the public-school manager. The methodology adopted was exploratory, with a qualitative and quantitative approach. For data collection, a validated instrument with 27 questions was used. A total of 111 managers of the basic education schools that make up the public-school system in a city in the northwestern region of Paraná, Southern Brazil answered to the questionnaires. When analyzing the results, it was investigated only those practices that were related to the structuring of organizational processes. This decision is justified because of the responsibilities of the school manager in the execution of his/her work. The results indicated that the school in its daily routine use practices of Knowledge Management related to the structuring of the organizational processes and that many are already applied by the managers.
\end{abstract}

Keywords: School management; Knowledge management practices; Organizational processes. 


\section{Introduction}

The knowledge management $(\mathrm{KM})$ is a very discussed theme nowadays, as well as its implantation levels and reach. In the extent of the school organization, it also wins space and it can contribute in a satisfactory way with the different dimensions delineated by National Council of the Secretaries of Education (CONSED). Those dimensions are considered as base for effective learning and they are the listed in the following manner: management of education results, pedagogic management, people management, participatory management and management of services and resources. Studies confirm the importance of the practices of management of the knowledge in the organizations, but it is still scarce the research on the subject returned to the organizational processes that they link with the people management (Batista, 2004; Batista, 2006; Batista, 2012; Davenport \& Prusak, 2003).

In the context of the school organization, understood as democratic space which, involves the field of the collective and conscious participation in the decisions taken to orientate, to drift and to execute the actions in all the dimensions of the school organization to play that role, demands a new profile, whose great challenge for the school manager is to offer quality education, without leaving aside the other segments of the school, as the pedagogical, the financial, the administrative, the legal, besides establishing a good relationship with the community (Freitas et al., 2002).

Knowledge happens from everyone's interpretation, in which one builds it according to the capacities and the reality where one is or lives with. Those constructions always happen inside of the patterns of assimilation of each learning. This way, it is understood that the development of knowledge can be understood as a social construct stepped on the political, economic and cultural determinations that moves society. Such interaction happens from models and instruments that start to orientate the individual's relationships or organization. According to Vasconcelos (2000), the creation of the knowledge feels as the ability of interacting with the social processes, what happens in a different way from an individual to another, as well as for the organizations and, based on what is intended to share, to create, to use or to register.

Nonaka and Takeuchi (2008) contribute defending that the knowledge comes in an explicit and tacit way. When built through experiences and formal education lived by the individuals, expressed by words, information, encyclopedias, theories etc. it is understood as explicit knowledge. Regarding the tacit knowledge is that acquired through experiences lived by the individual, being difficult to be shared, because it is a private ability.

The socialization of the knowledge, according to Davenport and Prusak (2003), generates a new knowledge, independent if this had been conceived in the tacit or explicit format. Nonaka and Takeuchi (2008) regarding the conception of the knowledge, highlight four types of occurrences, in that the knowledge happens and it compares it to the format of a spiral. They are socialized in situations in which the knowledge occurred, in other words, of tacit for tacit. Regarding the externalization, it is when the tacit knowledge is represented in explicit concepts. About the combination it is related to the sum of new knowledge to the existent, explicit for explicit. Concerning Internalization, this represents the incorporation of the explicit knowledge to the tacit. 
Inserted in this dynamic of knowledge and, facing the expectations regarding the quality education, the dimensions under the land of the school management, will be able to subsidize by the characteristics of the Knowledge Management, to promote important contributions. The vision of Grotto (2001, p. 35) regarding the Knowledge Management is "[...] like the process of promoting and managing the generation, the sharing, the use and the knowledge measurement, experiences and specializations in the organizations". According to Magalhães (2005, p. 87), "[...] the theory of the creation of organizational knowledge seats, therefore, in the relationship among people in all the levels - individual, group, organizational and inter-organizational".

In the field of the management, Vieira, Almeida and Alonso (2004, p. 74) reinforce that the school manager, drives his actions under the conception of the "co-responsibility, partnership, cooperation, interaction, solution of problems in common, dialogue, approach of all the interested parties". Santana et al. (2012, p. 63) point out for the changes of the society and the demands of the school management in that the "[...] education management should consider: the challenges that are put to the education demanding constant revisions in the formulation of the education objectives and the changes in the society (Santana et al., 2012).

In this constructive element, the sharing and the distribution of the knowledge require trust, so that it can disseminate innovative and creative ideas. That happens in the transition of the individual's knowledge for the group or for the organization. The way as the goals of knowledge are "[...] formulated determines the ways for the which can be assessed" (Probst et al., 2002, p. 36).Thus, it can be understood that the establishment of the goals is directly related to the evaluation of the knowledge.

According to Gupta and McDaniel (2002), people have opposed mental models, starting from which all the information will be appraised, interpreted and become different knowledge. Davenport and Pruzak (2003, p. 6) describe knowledge as "[...] a flowing mixture of condensed experience, values, contextual information and experienced insight, which provides a structure for the evaluation and incorporation of new experiences and information".

The individuals that compose an organization, when motivated and capable to adapt to new models as structure, processes and managerial systems, easily will understand and make use of the tools made available by the Knowledge Management. Understood by (Terra, 2015) as tool that administers the intellectual capital. Or better, it makes that the employees improve his/her development at work, and consequently the satisfaction and the competitiveness.

Constituted by practices that use the knowledge in the processes and in the improvement of the organizations, the practice of the Knowledge Management implicates in the understanding that people are not mere processors of information, but creators of the knowledge (Magalhães, 2005). In that sense Nonaka and Takeuchi (1997) highlight that the Knowledge Management is composed of actions that consist, in a systematic way, to produce, deposit, transmit and apply the knowledge so that the practices and individual collective knowledge are associated. 
Facing the exposed, this work had as central objective, to identify which is the level of implantation of practices of management of the knowledge for the structuring of the organizational processes, used by the manager of the public school that can favor the quality education. The investigation had participation of 111 managers of basic education schools that compose the public system of teaching in a city of the northwest area of Paraná, South of Brazil.

The adopted methodology was exploratory research, of qualitative and quantitative approach. The method of the qualitative research considers the meaning that the subject attributes to the practice being, therefore, the one that builds and participates in his/her history (Alves-Mazzotti \& Gewandsznajder, 2004).

The results of the quantitative research can be presented upon the mathematical language to describe the causes and results of the research. The quantitative research is centered in the objectivity and "[...] it considers that the reality can only be understood based in the analysis of gross data, collected with standardized and neutral instruments" (Fonseca, 2002, p. 20).

Regarding the procedure, for data collection, it was used of a questionnaire of practices of Knowledge Management with 27 subjects. That instrument is the same adopted by the Institute of Economic Applied Research (IPEA) already appraised and used thoroughly by Batista (2006), Batista (2012).

The questionnaire had been applied during a meeting of continuous formation for school managers promoted by the Program of Excellency in the Basic Education (PEEB) on October 09th, 2017. PEEB is a program of institutional extension of the Center of Higher education of Maringá (UNICESUMAR), registered in the section of research of the institution since 2013 under the number 084896. Its focus is to investigate which are the impacts in the school and in the quality of the education considering the aspects: school management, with the teacher, family, organized civil society and the student of the basic education of the municipality public school.

Participate of PEEB, through agreement term signed among UNICESUMAR, the city's Mayor and the Secretary of Education, 33 cities of the northwest area of South Paraná of Brazil.

In the moment of the formalization of the agreement, it is granted authorization for data collection and researches in the school area of the municipal system of that city and both parts are guided and explained regarding the need of the ethics and secrecy regarding the data and generated information.

For the research, it was limited to just one city, due to opportunity of the school managers' total concentration in the same area, besides being the city with the larger number of schools, that is, 111. Before starting to answer to the questionnaires, it was presented to the participants information on the purpose as well as the warranty that they would not be identified, nor their names be associated to any answered item. After the permission and, acceptation to participate, the questionnaire was answered at the end of the formation meeting and given directly to the present team of researchers.

Despite the questionnaire having 27 questions, at this time it was explored only those that are framed as belonging to the category of organizational processes practices, as: Benchmarking; Best practices; Organizational intelligence; Knowledge mapping; Administration for competence; Bank of organizational 
competence; Bank of individual competences; Administration of the intellectual capital (Batista, 2006; Batista, 2012).

Knowledge nowadays is a factor of extreme importance for the organizations, because it is built in the relationship among individuals, it is dependent of their capacities and it serves as a source of advantage, competitive and maintainable, being capable to provide the differential necessary where they act or in that they intend to reach. In that context, aiming to reach the objective proposed, it is believed that the implantation of practices of Knowledge management focused on the managerial processes, even if used intuitive and unsystematically for the school managers, can indicate the paths and experiences for better use of the intellectual capital that composes the professional team of the schools under his/her management.

The school administration involves the field of the collective and conscious participation in the decisions taken so that these are to orientate, to drift and to execute the actions in all the dimensions of the school organization. To play that part, it demands a new profile, whose great challenge for the school manager is to offer a quality education, without leaving aside the other segments of the school, as the pedagogic, the financier, the administrative, the legal, besides establishing a good relationship with the community (Freitas et al., 2002).

The education manager's performance, until recently, was related just to his/her vision or competence (Brown et al., 2014). However, his/her work cannot only be seen as the one of a professional exclusively concerned with bureaucratic demands. Taking as base the Federal Constitution of 1988, (Freitas et al.,2002) it highlights the need to adopt an administration pattern where the participation of those involved is collective to guarantee the quality of the education.

For Gonçalves and Sposito (2002), the school management aims to organize the internal and external demands of the school promoting the development of the actions and attitudes for the practical action and, above all in the sphere of its work. Effective school management relies on the processes of the different dimensions that fall under its scope of actions and cannot be limited to the figure of the director (Naz and Rani, 2016). It should be diluted and shared among all those who are part of the organization's professional team. Libâneo (2013) complements that the understanding of what comes to be school management goes beyond having a professional who directs the organization in the way that suits him/her best. School management or being a manager of a school organization requires a paradigm change of centralized and unilateral power. School management involves the field of collective and conscious participation in decisions taken so that these serve to guide, plan and implement actions in all dimensions of school organization (Lubwama et al.,2017).

Lück (2009) argue that management performed competently and committed to the interests of the school and community has a positive effect on the learning process. The school management format is that it triggers the learning process and delineates the actions and methodologies so that everything happens in an effective and with quality.

To play this role, there is a need for a new managerial profile that "[...] demonstrates proven merit and competence, be leaders, develop participatory and democratic leaders in their environment, besides being safe enough to live with other leaders" (Freitas et al., 2002, p.42). The great challenge for the school 
manager is to offer a quality education, without neglecting the other segments of the school, such as pedagogical, financial, administrative, legal, and establishing a good relationship with the community.

In the school organizational context, it is fundamental that the manager knows the totality of the dimensions that composes it and a great ally in this task is the Knowledge Management that has been standing out in the school organizations, both public and private, in the configuration of strategic resource for the management. The educational system based on Knowledge Management has, as its prerogative to stimulate the skills that those involved offer and, later, the competences that each person has individually (Emydio \& Rocha, 2012).

Although organizations begin to stimulate knowledge, acquiring it often is a long and confusing process. The ways of using it are multiple and unpredictable because the individual must produce knowledge in a way that facilitates cooperation in their daily activity (Hartnell et al.,2011).

Organizations seek to use Knowledge Management to transform themselves into spaces that stimulate learning and the creation and sharing of knowledge, especially in the private sphere, where there is the constant challenge of generating new services and products, driven by the competitiveness of the market. Although Knowledge Management practices are commonly used in the business and industrial areas, these resources can also be directed to the school environment, since kept the appropriate proportions and comply with the laws that govern the school institution.

The practices of Knowledge Management were divided by Batista (2006) and Batista (2012) into three categories. They are: Management of human resources: which aims to assist the manager in the construction of a qualified team that contributes in a natural way to organizational learning, facilitating the transfer, dissemination and sharing of knowledge and information. In the format of practice, there are the following examples: Forums/discussion list; Corporative education; Narratives; Mentoring; Coaching; Corporate University; Practical community.

The category structure of organizational processes is a practice with the purpose of facilitating the generation, organizational retention and dissemination of organizational knowledge. Benchmarking; Best Practices; Organizational intelligence; Knowledge mapping; Management by competence; Bank of organizational competence; Bank of individual competences; Management of intellectual capital are some of the existing examples.

The technological and functional basis support the management of organizational knowledge, including automation of information management, applications and Information Technology tools for capture, diffusion and collaboration. Portals/intranets/extranets; Workflow System; Content Management; Electronic document management; Data warehouse; Decision Support Systems; Balanced Scorecard; Data Mining; Customer Relationship Management; key performance indicators; Enterprise Resource Planning illustrate a set and possibilities.

Highlighting the relevance of the use of practices and tools of the Knowledge Management in the structuring and transport of the managerial processes in a school organization and defending that they are already part of the routine, through Table 1 it is possible to observe the relationship of applicable practices 
in the development of the demands of the school context and which would be their users.

Table 1. Practices of the Knowledge Management related to managerial processes used in the context

\begin{tabular}{|c|c|c|}
\hline Practices & School context & User \\
\hline Benchmarking & $\begin{array}{l}\text { Institutional } \\
\text { evaluations, Plannings } \\
\text { and Council of Class. }\end{array}$ & $\begin{array}{l}\text { Teachers, coordinators, } \\
\text { technician-administrative } \\
\text { employees and direction. }\end{array}$ \\
\hline Best practices & $\begin{array}{l}\text { Change of experiences, } \\
\text { Pedagogic Meetings. }\end{array}$ & $\begin{array}{l}\text { Teachers, coordinators, } \\
\text { technician-administrative } \\
\text { employees and direction. }\end{array}$ \\
\hline $\begin{array}{l}\text { Knowledge } \\
\text { mapping }\end{array}$ & $\begin{array}{l}\text { Rising or registration of } \\
\text { all the processes, } \\
\text { existent services in the } \\
\text { school context. }\end{array}$ & $\begin{array}{c}\text { Director and } \\
\text { administrative team. }\end{array}$ \\
\hline $\begin{array}{c}\text { Bank of } \\
\text { individual } \\
\text { competences }\end{array}$ & $\begin{array}{l}\text { Pedagogic meetings, } \\
\text { Planning. }\end{array}$ & $\begin{array}{l}\text { Teachers, pedagogic } \\
\text { coordinators and } \\
\text { technician-administrative } \\
\text { employees. }\end{array}$ \\
\hline $\begin{array}{l}\text { Organizational } \\
\text { Intelligence }\end{array}$ & $\begin{array}{l}\text { Parent Meetings, School } \\
\text { Board, Student Group. }\end{array}$ & $\begin{array}{l}\text { Families, student, teachers, } \\
\text { technical-administrative } \\
\text { employees and direction. }\end{array}$ \\
\hline $\begin{array}{l}\text { Organizational } \\
\text { Memory }\end{array}$ & $\begin{array}{l}\text { Lectures and courses, } \\
\text { change of experiences, } \\
\text { Pedagogic Week. }\end{array}$ & $\begin{array}{l}\text { Teachers, pedagogic } \\
\text { coordinators and direction. }\end{array}$ \\
\hline $\begin{array}{l}\text { Management } \\
\text { of the capital } \\
\text { intellectual }\end{array}$ & $\begin{array}{c}\text { Council of Class, } \\
\text { pedagogic meetings, } \\
\text { Plannings. }\end{array}$ & $\begin{array}{l}\text { Teachers, coordinators, } \\
\text { technician-administrative } \\
\text { employees and direction. }\end{array}$ \\
\hline $\begin{array}{l}\text { Management } \\
\text { by } \\
\text { competences }\end{array}$ & $\begin{array}{l}\text { Training and formation } \\
\text { courses. }\end{array}$ & $\begin{array}{l}\text { Teachers, coordinators, } \\
\text { technician-administrative } \\
\text { employees and direction. }\end{array}$ \\
\hline
\end{tabular}

At school, there are several instances where practices and tools are and should be emphasized to benefit the performance of the school manager. Recognize and take ownership of the advantages that Knowledge Management offers for building and sharing knowledge, shortens paths, minimizes efforts, avoids rework and strengthens the team. In this harmonious atmosphere of exchange, motivated by the collaboration of all involved and in this case stands out the professionals of the school, quality education is closer to being cultivated.

\section{Materials and Methods}

The methodology used was of exploratory nature. Regarding the type of approach, it is configured as a qualitative and quantitative, with the participation of one hundred and eleven managers of basic education schools. These schools belong to the public school system of a city in the northwestern region of Paraná, southern Brazil. These managers are all pedagogues whose experience in teaching of at least two years and 18 at most. 
When applying the questionnaire, all the survey participants, that is, the 111 school managers in the public school were informed about the purpose of the instrument application and how the data would be processed.

Noting that the schools they run are part of the group of thirty-three cities agreed with PEEB and that the formalization documents are signed and recognized as authorization for data collection. At the time of application, the supporting documents were available to those who had an interest in checking. On the part of the managers who answered the questionnaires, there was consent and, therefore, the application was carried out.

Regarding the questionnaire, it is an instrument already validated by Batista (2006) and Batista (2012), composed of 27 questions about Knowledge Management practices. The questionnaire presents a list of practices of Knowledge Management that are categorized as: human resources management; structuring of organizational processes, technological and functional basis. Beside each practice was the description of its application to clarify the manager before indicating the alternative for answers. Answers could be posted in column " $\mathrm{A}$ " or " $\mathrm{B}$ " where option " $\mathrm{A}$ " represented the Implantation stage and the " $B$ " Reach within the organization. Before choosing the alternative, it was necessary to use a guidance menu arranged in the questionnaire header. This menu lists a scale from zero (0) to four (4) for Implantation Stage and one (1) to four (4) for Reach within the organization.

After tabulation and interpretation of the data, it was decided to analyze at this moment only the practices that were related to the structuring of organizational processes since a high incidence of "low level" was observed regarding the scope in this category that can be considered support for the management of the school.

\section{Results}

To answer the questionnaire, school managers had as their option a Likert scale organized into a set of four alternatives where one (1) refers to "few isolated initiatives within the organization"; two (2) "some departments use practice"; three (3) "Many departments use practice"; four (4) "widely disseminated in the organization".

When analyzing the questions, it was obtained the relative frequency for each one of the answers. The relative percentage of the alternatives of each question was transformed into a weighted average. When compiling the data and the distribution of the frequency of responses, another variable was observed, that of those who did not respond (n/r), which was also considered in the interpretation and classification of the results that can be observed in Table 2 . 
Table 2. Frequency distribution in percentile of the Likert scale - implementation of the relative practices to the structuring of organizational processes in the school

\begin{tabular}{llllll}
\hline \multirow{2}{*}{ Practices } & \multicolumn{5}{l}{ Implantation stage } \\
\cline { 2 - 6 } Benchmarking & $\mathbf{1}$ & $\mathbf{2}$ & $\mathbf{3}$ & $\mathbf{4}$ & $\mathbf{n} / \mathbf{r}$ \\
\hline Best practices & 4.9 & 15.9 & 17.1 & 59.8 & 2.4 \\
\hline Knowledge mapping & 12.2 & 18.3 & 32.9 & 35.4 & 1.2 \\
\hline Bank of individual competences & 26.8 & 22 & 22 & 26.8 & 2.4 \\
\hline Organizational intelligence & 40.2 & 23.2 & 13.4 & 18.3 & 4.9 \\
\hline Bank of organizational competences & 22 & 19.5 & 30.5 & 25.6 & 2.4 \\
\hline Management of the intellectual capital & 12.2 & 22 & 29.3 & 29.3 & 2.4 \\
\hline Administration for competences & 23.2 & 23.2 & 29.3 & 22 & 2.4 \\
\hline Averages & 19.8 & 19.3 & 23.4 & 32.3 & 3.3 \\
\hline \multicolumn{1}{c}{ Source: Data of the Research $(2018)$} & & &
\end{tabular}

Source: Data of the Research (2018).

By analyzing the frequency in more details, it was possible to identify the level of implementation of these practices. In Table 3, the results analysis scale of the implementation level of the practices that subsidize the structuring organizational processes can be observed. It presents the effective level of implementation of these practices of Knowledge Management.

Table 3.Results analysis scale of the level of implantation of the practices of structuring organizational processes.

\begin{tabular}{cc}
\hline $\begin{array}{c}\text { Effective level of implementation } \\
\text { of the practices of Knowledge } \\
\text { Management }\end{array}$ & Results \\
\hline Low level & Between $0 \%-39 \%$ \\
\hline Medium level & Between $40 \%-60 \%$ \\
\hline Hig. level & Between $60 \%$ \\
\hline
\end{tabular}

Elaborated by the authors (2018)

According to the parameters adopted for the research, it was found that, on average, $23.4 \%$ of the managers considered that the knowledge management practices related to the structuring of organizational resources are already implemented, and $32.3 \%$ stated that, in addition to already being implanted, such practices present important results for the organization. That is, on average, $55.7 \%$ of managers consider that these practices are already part of daily life. Of these practices, Benchmarking with $59.8 \%$ was the practice that set the average level, presenting the greatest result regarding the implementation in schools. Identified as present in institutional assessments, planning and class councils. The practice of the Bank of individual competences with $18.3 \%$ was the one that presented the lowest level of implementation in the schools, consisting of pedagogic meetings and pedagogic week. Knowledge Mapping, understood as a survey or recording of all school information, including processes, services and 
the relationship between them, represented $26.8 \%$ of what is considered low level.

Organizational Intelligence that is represented by teacher and student, pedagogical team, director, administrative and support team stood with $25.6 \%$ which means low level \%. On the other hand, the Banks of organizational competences that are the qualification and training courses attended by all the professionals of the school, points to $29.3 \%$, that is, low level. About Management by competences, qualification and training courses that is also a practice that involves all staff, shows as a result $22 \%$, also at low level. As for the Best practices that are the exchanges of experiences that can occur during the pedagogic meetings involving all the professionals of the school, presents $35,4 \%$ which results in low level of implantation, whereas Intellectual capital management appears with $41,5 \%$ present in class councils, pedagogic meetings, have middle level planning.

\section{Conclusions}

The results indicate an average level of implementation of practices related to the structuring of organizational processes, although some are already applied by managers and present important results for the organization. It is concluded that the implementation of knowledge management practices, even if used intuitively and unsystematically by the managers of the schools investigated, can direct or present experiences to better use the intellectual capital involved. Under this approach and in accordance with the initially proposed objective of identifying the level of implementation of knowledge management practices aimed at structuring the organizational processes used by the public school manager, it is emphasized that they favor the integration of people in and out of school. They provide exchanges of experiences, dialogues, reflections and the involvement of everyone with school issues. The practices involved, Benchmarking; Best Practices; Organizational intelligence; Knowledge mapping; Management by competence; Bank of organizational competence; Bank of individual competences; Management of intellectual capital, whether for its purpose or through those involved, in some way, relate in the construction and sharing of knowledge.

All this volume of actions from the Knowledge Management point of view, can offer representative subsidies for the exercise of school management. It is concluded that it is valid to invest in the use of such practices and that even if they are part of the day-to-day work in the school context, one must not exploit them in a strategic way in favor of the harmony of the people that make up the organization, for the improvement of the processes, identification of the gaps or weaknesses that can be announced. It is also defended the relevance of investing effort in the study, not only of the practices listed here, but also with the others that are configured with strong allies to support the school manager.

\section{References}

Alves-Mazzotti, A.J. \&Gewandsznajder, F. (2004).The Method in the Natural and Social Sciences: Quantitative and Qualitative Research. 2. ed. São Paulo: Pioneira.

Batista, F. F. (2004).I govern that learns: administration of the knowledge in the federal executive's organizations. Text for discussion $n^{\circ} .1022$. 
Batista, F. F. (2006).The challenge of the administration of the knowledge in the administration areas and planning of the Federal Institutions of Higher education (IFES).Text for Discussion, n 1181. IPEA, Brasília.

Batista, F. F. (2012).Model of administration of the knowledge for the Brazilian public administration: as it implements the administration of the knowledge to introduce results in benefit to the citizen. Brasília: IPEA.

Brown, M., Owusu, A. A. (2014). Influence of Head Teachers Management Styles on Teacher Motivation in Selected Senior High Schools in the Sunyani Municipality of Ghana, International Journal of Learning, Teaching and Educational Research Vol. 4, No.1, pp. 61-75, April 2014.

Davenport, T. \&Prusak. (2003).Business knowledge: As the organizations they manage his/her intellectual capital. 10. ed. Rio de Janeiro: Campus.

Emydio, M. M.\& Rocha, R. F. (2012). Knowledge Management in the Educational Area: Technology as a Facilitating Instrument. In. Symposium on Excellence in Management and Technology, 9. (2012). Resende. Anais electronic Resende: AEDB (2012).Retrieved fromhttps://www.aedb.br/seget/arquivos/artigos12/31316263.pdf.

Freitas, K. S., Girling, R. \& Pinheiro, J. X. (2002). Education politics and the Administration of the Public School: culture, leadership and legislation. Brazilian journal of education policy and administration (RBPAE), V.18, n. 1, Jan / Jul, p. 42 -52.

Goncalves L. A. \& Sposito M. P. (2002).Public initiatives to reduce school violence in Brazil. Research Notebook.

Grotto, D. (2001). A look at knowledge management. Journal of Management Sciences. Florianopolis, year 3, n. 6, p. 31-37, September.

Gupta, A. \& McDaniel, J. (2002). Creating Competitive Advantage by Effectively Managing Knowledge: A Framework for Knowledge Management, Journal of Knowledge Management Practice, October.

Hartnell, C. A., Ou, A, Y. \& Kinicki, A. (2011) Organizational Culture and Organizational Effectiveness: Analytical and analytical investigation of the theoretical assumptions of the competing values framework. Journal of Applied Psychology, 96 (4), $677-$ 694. Obtained from https://doi.org/10.1037/a0021987.supp. Date Posted: Set. 082018

Libâneo, J. C. (2013). Degree in Pedagogy: absence of specific contents of elementary education. In: Gatti, Bernadete Angelina et al. (Org.). For a National Teacher Training Policy. São Paulo: UNESP, p. 73-94.

Lubwama, J., Onen, D., Kasenene, E., S. (2017) Influence of Management on Quality Assurance in National Teacher's Colleges, International Journal of Learning, Teaching and Educational Research. Vol. 16, No.11, pp. 138-156, November 2017 https://doi.org/10.26803/ijlter.16.11.8

Lück, H. (2009).School management dimensions and their competences. Curitiba: Editora Positivo.

Fonseca, J. J. S. (2002). Methodology of scientific research. Fortaleza: UEC (2002). Apostila.

Magalhães, R. (2005).Fundamentals of organizational knowledge management. Lisbon: Sílabo.

NAZ, S., RANI, F. (2016). The impact of leadership styles of principals on the performance of the teacher at the secondary level, Karachi, Pakistan. RADS Journal of Social Sciences and Business Management, [Sl], v. 3, n. 2, p. 18-26, Jan. 2016. ISSN 2522-3208. Available at: <http://jssbm.juw.edu.pk/index.php/jssbm/article/view/22>. Date Posted: Nov 032018

Nonaka, I. \& Takeuchi, H. (1997).Creation of Knowledge in the company: how Japanese companies generate dynamics of innovation. Rio de Janeiro: Campus.

Nonaka, I. \& Takeuchi, H. (2008).Theory of the creation of organizational knowledge. In: Takeuchi, H.; Nonaka, I. Knowledge management. Porto Alegre: Bookman, p. 54-90. 
Prost, G; Raub, S. \&Romhart, K. (2002).Knowledge management: the constructive elements of success. Porto Alegre: Bookman.

Santana, S. S., Gomes, R. S. \& Barbosa, J. S. (2012).The role of the manager in the elaboration and execution of the pedagogical political project in a democratic vision. Booklets of Pedagogy, São Carlos, v. 6 n. 11, p. 62-73.

Terra, J. C. C. (2015).Knowledge management: the great business challenge. Earth forum consultants.

Retrieved fromwww.terraforum.com.br/biblioteca/Documents/libdoc00000011v002Gestao\% 20do\%20Conhecimento_\%2.20\% 20\% 20de.pdf. Date Posted: Oct. 012018

Vasconcelos, M. C. R. L. (2000).University Business Cooperation in Graduate Studies: Contribution to Learning, Knowledge Management and Innovation in the Mining Industry. Belo Horizonte: School of Information Science, UFMG, 257p. (Thesis, Doctorate in Information Science).

Vieira, A. T., Almeida, M.E. B.\& Alonso, M. (Org.). (2004). Educational management and technologies. São Paulo: Avercamp. 